\title{
Impact of Russian Medical Secrecy and Data Restriction Laws on Research
}

\author{
${ }^{1}$ Kamil M. Arslanov, ${ }^{2}$ Ayrat R. Davletshin \\ ${ }^{1}$ Kazan Federal University Cand. of Juridical Sciences, Docent, Head of Department of Civil Law \\ ${ }^{2}$ Kazan Federal University, Assistant of Department of Civil law \\ E-mail:kam.arslanov@gmail.com,davletshin@mp-law.ru
}

Received: 20 ${ }^{\text {th }}$ August 2019, Accepted: 30 ${ }^{\text {th }}$ September 2019, Published: 31 ${ }^{\text {st }}$ October 2019

\begin{abstract}
A feature of non-property rights is their non-material nature, as well as the fact that the law does not determine the limits for their enjoyment but establishes the boundaries of invasion of personal privacy of others. In civil law, non-property rights are recognized as independent subjective rights, the task of which is to protect the privacy of a person from outside interference.

The paper analyzes various interbranch connections of law, the mutual influence of private and public interests in establishing a regime of medical secrecy.

Medical secrecy means a special legal regime of restricted access data, which differs from other legal regimes in its focus on organizing information about a person's life and health as non-material values belonging to him from birth. The goal pursued by the establishment of a special regime of medical secrecy is to balance the private and public interests, taking into account the fact that human life is the most important value. The Russian Constitution interprets life as the very first and most important intangible benefit (Article 20 of the Russian Constitution).

The authors conclude that organizing information about human life and health, establishing an appropriate regime is important for both the patient (private interest) and society as a whole (public interest). Public interest arises, for example, when it comes to certain diseases that threaten the life of society. Therefore, it is important to establish the correct mode of information about human life and health - the establishment of medical secrecy.
\end{abstract}

\section{Keywords}

Life and Health, Medical Secrecy, Interbranch Connections, Private and Public Interest, Civil Law Regime, Information About Life and Health, Medical Secrecy Regime, Personal Non-Property Relations.

\section{Introduction}

In case of secrecy consisting of specific information, it should be noted that the latter is governed by certain legal regimes that provide the necessary protection. The emergence of this kind of legal regimes of restricted access is connected with the development of information technology and an increase in the volume of information in general [1]. The fundamental role is played by the specifics of personal non-property relations developing around medical secrecy. Therefore, it is necessary to establish the legal nature of medical secrecy. However, before this, it is important to determine which branch of law medical law itself belongs to, since, based on the answer to the question posed, it will be possible to define what medical secrecy is. An analysis should also be made of what legal regulation is received by personal non-property relations, in general, and medical secrecy, in particular.

Medical law is a system of rules governing public relations in the field of health care, the provision of medical care and services [2]. Based on the subject of regulation and political and legal ideas that the legislator invests in the idea of legal regulation, it can be concluded that the imperative method is prevailing, but private law methods are used for individual institutions. Therefore, a theoretical basis is needed to justify that regulation may be interbranch inherent in various branches of law. Interbranch legal regulation should be understood as the use of legal means inherent in different branches of law. A certain community of public relations regulated by law predetermines interbranch legal regulation. In particular, such a community in the field of consumer protection was formed with the help of goal-setting - the need to ensure comprehensive legal protection of the legal rights of the weaker party [3].

An authorized person is opposed by an indefinite number of subjects, while non-property rights are absolute. A person is free to determine behavior in the process of life, interference in the private sphere is excluded, except as provided by law, which is the basis of civil law protection of privacy [4].

\section{Materials and Methods}

The presented investigation was based on data formulated in domestic and foreign doctrinal and legislative sources. General scientific (logical, system-structural, analysis, synthesis) and private-scientific methods are used.

The instrumental theory of law is used as a fundamental theoretical and methodological background, which represents law as a specific system of legal means, combined in separate sections of legal regulation into unique mechanisms and regimes that provide an effective solution to socio-economic, political, cultural and other problems. The analysis of law as a system of legal means inevitably affects many major problems of the theory of law and legal practice.

The instrumental theory of law in this paper was used in conjunction with the sociological approach, which represents law as an integral part of the social system charged with a function for serving it. It is through such a methodological 
prism that one can most effectively approach the issue of medical secrecy, since this is a complex phenomenon that goes beyond the scope of law and requires a broadside and multifaceted approach.

\section{Results}

Based on the provisions of Article 9 №149-FL “On Information, Information Technologies and Information Protection”, it should be concluded that information with restricted access is divided into state secrets and confidential information. The information law refers commercial, official, professional, personal and family, as well as other secrets, to information in relation to which confidentiality compliance is mandatory. By virtue of the second part of Article 9 of the said law, it is established that confidentiality of restricted access information, according to federal laws, is mandatory. In this case, it can be established that the imperative method of regulation is used. However, an indication of the imperative nature of the regulatory method is clearly not enough to determine affiliation with any branch of law. There is a goal-setting that the legislator uses when choosing a particular regulatory model. In the case of the above legislative act, it can be noted that imperativeness is used in accordance with the goal of limiting access to information in order to protect certain values. Thus, we can talk about the presence of public interest [5].

The famous economist Hayek F.A. believes that "public interest can be interpreted as the need to maintain a spontaneous order which is a means of helping to achieve a huge variety of personal goals" [6], while the term "public" indicates that this formalization is carried out by the subject of public authority. Thus, public interest can be called "objectified public interest" [7]. However, it should be noted that not always public interest can be converted from the objectification of public interest. This may be due either to the fact that the public interest to some extent diverges from the state interest in the security sphere, or the state, due to the fact that this is just an abstraction behind which the state apparatus hides is rigid and behind the changes taking place. However, in general, one can agree with the opinion when public interest is transformed from social interest. An example is the provision of Article 2 of the Constitution of Russia: "The bearer of sovereignty and the only source of power in the Russian Federation is its multinational people."

From a methodological point of view, it is necessary to establish a balance of private and public principles in the regulation of a particular public relation. However, such an analysis is not possible via abstract analysis; corresponding theoretical foundations are necessary. That is why it is necessary to turn to the doctoral dissertation of Professor, Doctor of Law M. Y. Chelyshev - "The System of Interbranch Connections of Civil Law: A Civil Study": "Since any normative act acts as a system formation with its own internal structure, one of the main methods of studying intersectoral relations of civil law, reflected in the indicated sources, is the analysis of the indicated connections according to the structure of the corresponding Act" [8]. Investigating the intersectoral relationship of medical law, further consideration of regulatory acts in this area is essential.

Some scientists, analyzing different types of secrets that differ in the categories of information protected by law, consider the damage that may be caused in the event of the dissemination of information as a common attribute that unites them. In their opinion, it makes no sense to conceal anything if there is no danger of the onset of harmful consequences [9]. In particular, V.N. Lopatin sees about 40 types of secrets in the current regulatory legal acts and offers the classification of restricted access information:

- State secret;

- Confidential information.

At the same time, he refers "commercial secrets, banking secrets, professional secrets, personal data and official secrets" to confidential information [10].

It is worth pointing out to the Decree of the President of the Russian Federation dated March 06, 1997 № 188 “On approval of the list of information of a confidential nature" [11], which gives an exhaustive list of types of confidential information: personal data, confidentiality of the investigation and legal proceedings, official secrets (in view of changes to the Civil Code, this institution practically ceased to exist in Russia, article 139 "official and commercial secret" (ineffective since January 01, 2008), professional secret, commercial secret and information about the essence of the invention, utility model or industrial of the sample to the official publication of information about them. However, the list of types of information is exhaustive, but not the composition of information of a confidential nature within these types. This regulatory act is valid, and therefore, to clarify the essence of medical secrecy, it must be compared precisely with these types of information of a confidential nature. From the point of view of the analysis of the presentation of the legal technique, we can conclude that the interbranch method of regulation is used, since it is initially established that the list is exhaustive, but its composition is not, that is, there is no indication of the mandatory inclusion of any elements.

According to most representatives of modern legal science, medical secrecy can be classified as professional secrecy. Medical secrecy is based on confidential relations between the patient and the medical institution, which imposes the relevant features of legal regulation [12]. It is necessary, in our opinion, to understand how professional and medical secrecies are related, whether they can be compared as general and particular. Or there are significant differences between these categories, excluding the possibility of considering them as general and particular.

From this point of view, it is important to note that the protection of information constituting a medical secret occurs due to the very fact of the existence of legal relations between the medical institution and the patient. This is due to the nature of the information of medical secrecy since they relate primarily to the life and health of the patient. A medical organization is not able to derive a profit from the protection of medical secrecy. On the contrary, security is associated with certain costs of the institution. No patient confidentiality fee may be charged. 
According to the legal scientific doctrine, the obligation to protect medical secrecy should not cease after the transfer or dismissal of the employee, as well as in the event of his retirement. In other words, it should not be limited by any time limits, it should act indefinitely [13]. However, such a requirement of the need to maintain medical confidentiality has not been legally established by law, which is a weak point in the chain of requirements for maintaining medical secrecy [14].

At the same time, this institution cannot be absolutized. In accordance with the restrictions established in Article 55 of the Constitution of the Russian Federation, in order to protect the foundations of the constitutional order, morality, health, rights and legitimate interests of others, to ensure the defense of the country, the security of the state, individual rights may be limited. This provision serves as an indication that in this case the primacy of "public interest" is not only possible, but also has a logical justification.

Any citizen has the right to refuse medical intervention, however, to what extent this right is in conflict with the rules on the prohibition of euthanasia in Russia, it is necessary to analyze separately [15].

It should be noted that hopeless diagnoses suggesting refusal to continue treatment are not equal to refusal of medical care, in particular, in connection with ensuring a worthy death for the patient. There is a mixture of legal and ethical views of many scientists. Modern medicine has the ability to extend the process of dying of a patient using intensive care and resuscitation [16]. Here, the importance of raising the question of the positive use of the remaining time to patients is seen According to Article 43 of the Federal Law "On the Basics of Protecting the Health of Citizens in the Russian Federation", a council of doctors may decide to provide medical care against the will of the patient or legal representatives if the patient suffers from diseases that are dangerous to others or in the presence of severe forms of mental disorder, including in relation to the persons who committed socially dangerous acts (crimes). In addition to the consultation, such a decision can be made in court (issues of involuntary hospitalization). A stay in medical institution continues until all the grounds for involuntary hospitalization disappear. This norm is dispositive in itself, that is, it provides for discretion for a consultation of doctors, but its consequences are aimed at realizing public interests, that is, it combines private and public regulatory elements. The specified norm is an example of interbranch legal regulation considered in the framework of this study.

\section{Summary}

In connection with the foregoing, one can talk about the manifestation of the interbranch relations that develop around the patient's medical secrecy. Interbranch relations are manifested in the mutual influence of the norms of private and public (administrative) law.

The analyzed interbranch regulation is achieved via legal means used by various branches of law. So, the public relations that make up the subject of medical law are simultaneously regulated by both private law and public norms.

Professor, Doctor of Law V.F. Yakovlev believes that "the application of interbranch legal regulation in the current legislation is one of the reasons for the formation and development of complex legal branches and institutions with and without a civil component" [17].

Private regulation is applicable directly to secrecy. Specifically, we are talking about the possibility of applying measures of civil liability in cases of unlawful disclosure.

However, a public element can be highlighted in obligations regarding medical secrecy, for example, the obligation of a medical professional not to divulge the medical secrecy of patients in institution. This circumstance is also a confirmation of interbranch regulation of medical secrecy.

\section{Conclusion}

The identified interbranch connections are dynamic in the implementation of law and static in the law.

Currently, it can be noted that the study of both medical secrecy and secrecy in general is developing in the direction of legal regimes. The idea of securing the latter as objects of civil law has not yet been reflected in Russian law.

\section{Acknowledgements}

The work is performed according to the Russian Government Program of Competitive Growth of Kazan Federal University.

\section{References}

1. Davletshin A.R. The Concept of the Legal Regime of Medical Privacy // Eurasian Law Journal. - Issue 1 (128) 2019, - P. 203-206.

2. Arslanov K.M, Davletshin A.R., Medical Privacy as an Object of Civil Legal Relations [La privacidad medica como objeto de relaciones juridicas civiles] // Opcion. - 2018. - Vol.34, Is.86. - P.9-15.

3. Davletshin A.R. Civil Liability for the Breach of Medical Secrecy // The Main Trends in the Development of Modern Law: The Problems of Theory and Practice: Materials of the Third All-Russian Scientific and Practical Conference (Kazan, February 28, 2019) / Edited by Doctor of Law A.B. Mezyaev, Doctor of Law R.F. Stepanenko, Doctor of Law S.N. Tagaeva. - Kazan: Information Center of the University of Management “TISBI", 2019. P. 140-143. 
4. Taitsman, Julie K., Grimm, Christi Macrina, Agrawal, Shantanu. Protecting Patient Privacy and Data Security // The NEW ENGLAND JOURNAL of MEDICINE. 368;11 nejm.org march 14, 2013 (Downloaded from nejm.org on June 8, 2018). P. 977-979.

5. Hadeal Abdulaziz Al Hamid, Mizanur Rahman, M. Shamim Hossain, Ahmad Almogren, Atif Alamri. A Security Model for Preserving the Privacy of Medical Big Data in a Healthcare Cloud Using a Fog Computing Facility With Pairing-Based Cryptography, Access IEEE, vol. 5, 2017 (Downloaded from https://ieeexplore.ieee.org/stamp/stamp.jsp?tp=\&arnumber=8052485 on May 15, 2018). Pp. 22313-22328.

6. Hayek F.A. Law, Legislation and Freedom: a Modern Understanding of the Liberal Principles of Justice and Politics // M.: IRISEN, 2006. P. 170.

7. Kabanova I.E. The Principle of the Balance of Private and Public Interests in Doctrine and Law Enforcement Practice // Power of the Law. 2016. N2. P.74 - 84

8. Chelyshev M.Y. The System of Intersectoral Relations of Civil Law: Civil Law Research // The Dissertation for the Degree of Doctor of Law. Kazan, 2008, P. 238.

9. Fatiyanov A.A. Secrecy as a Social and Legal Phenomenon. Its Types // State and Law. - 1998. - Issue 6. P.6.

10. Lopatin V. N. Legal Safeguards and Правовая охрана и защита служебной тайны // Государство и право. 2000. - №6. - c.85-87.

11. On approval of the list of confidential information: Decree of the President of the Russian Federation of March 06, 1997. №188 (of September 23, 2005) // Russian Newspaper. - 1997. - March 14.

12. Arslanov K.M. Medical Obligation to Timely Inform the Patient About Medical Intervention (Experience of German Law) // Medical Law. 2016. № 4. P. 50-55.

13. Ann B. Nattinger Liliana E. Pezzin Rodney A. Sparapani Joan M. Neuner Toni K. King Purushottam W. Laud. Heightened Attention to Medical Privacy: Challenges for Unbiased Sample Recruitment and a Possible Solution. American Journal of Epidemiology, Vol. 172, Issue 6, 15 Sept. 2010 (Downloaded from https://doi.org/10.1093/aje/kwq220 on April 30, 2018). Pp 637-644.

14. Davletshin A.R. The Right to Doctor-Patient (Medical) Confidentiality and Qualified Legal Assistance// Kazan. University Transactions. Series Humanitarian Science. - 2017.- Vol. 159, B. 2. - P. 401-410.

15. Arslanov K., Nizamieva O. Surrogacy: Legal and Moral Dimension of the Problem from the Perspective of Russian, Foreign and International Experience // Research Journal of Applied Sciences. 2015. 10 (12). P.841844.

16. Arslanov Kamil M., Davletshin Ayrat R., Spouse right to medical privacy // INDO AMERICAN JOURNAL OF PHARMACEUTICAL SCIENCES. - 2018. - Vol.5, Is.12. - P.16870-16874.

17. Yakovlev V.F. Civil Law Method of Regulation of Public Relations // Sverdlovsk, 1972. - 210 p. - P.207. 